\title{
Perceptions on confronting sexual exploitation in Canada: Introducing new primary research
}

\author{
Robert (Bob) Chrismas*
}

\begin{abstract}
This paper provides a preview into new primary research into sexual exploitation and human sex trafficking in Canada. The project, for which interviewing is complete and analysis is now underway, is qualitative research taking a grounded, open-minded approach with an underlying hypothesis that better outcomes may be gleaned from systems of service providers and stakeholders through improved coordination and collaboration. Previous research on related topics has often overlooked key stakeholders including police, prosecutors, political, First Nations and other community leaders. This research casts a wider net, incorporating the voices of over 65 experts across Manitoba, including: experiential survivors of sexual exploitation and sex trafficking, police, social workers, Aboriginal leaders, and people working in numerous non-government organizations who work to prevent sexual exploitation and assist victims to escape the sex industry. The research was focused in Manitoba where women and children continue to be victimized in the sex industry despite having one of the most comprehensive and well-funded counter sexual exploitation strategies of any province in Canada. The questions asked of subjects were designed to highlight barriers and opportunities for improved collaboration, interdiction and response to prevent people from being exploited in the sex industry and help others to escape it. While the data is in the early stages of analysis, some strong themes are already apparent to the researcher. These themes suggest that there may be a significant correlation between vulnerability to sexual exploitation and poverty, lack of opportunities, familial environment and relationships, and resilience. Generally, people from all perspectives seem to be stressing that there needs to be better coordination of resources, and more education and awareness across society on this issue.
\end{abstract}

Key Words Exploitation, trafficking, prostitution, collaboration, collective impact

Journal of CSWB. 2016 Aug; $1(2): 4-6$

www.journalcswb.ca

\section{INTRODUCTION}

Human sex trafficking is a massive and growing industry with global profits exceeding US\$99 billion (US Department of State, 2014; Nelson, 2014; UNODC, 2014). The US Department of State (2014) estimates that each year about 800 people are trafficked into Canada and 1500-2200 people from other countries are moved through Canada into the United States. Trafficking, however, doesn't necessarily mean being taken across borders. Most Canadian trafficking victims are from within Canada (RCMP, 2014). The Criminal Intelligence Service of Canada (CISC, 2008) has estimated the average annual profit from each female trafficked in Canada is up to $\$ 280,800$, with daily profits of up to $\$ 1,000$ per day from each trafficked woman. So it is easy to see the attraction of the sex industry to organized crime.

The risks to people involved in the sex industry and the financial costs to Canadians are substantial. A recent Canada-wide study by the Canadian Women's Foundation (CWF, 2014) reported that 70 per cent of sexually exploited women use hospital services at least once during, and as a result of, their trafficking experience (for assaults, rapes, and other injuries) with costs of up to $\$ 820$ per emergency room visit, $\$ 785$ per ambulance trip, $\$ 1,115$ per day in hospital, $\$ 181,129$ for the average lifetime treatment cost for HIV/AIDS and $\$ 29,526.16$ average lifetime treatment cost for Hepatitis C. One-quarter of women in the sex industry reported not using condoms regularly or at all, thus increasing their risks. Other significant related costs are more difficult to quantify and can include: legal counsel, complex national or international criminal trafficking/exploitation investigations, social assistance and other services (CWF, 2014). Of course, the biggest costs are not financial; they are the long-term physical and psychological suffering that survivors endure.

Farley (2003) found that many women and youth involved in the sex industry are trapped in violent exploitative relationships, often fearing violence and suffering from severe substance abuse problems. Her study of 854 prostitutes in nine countries revealed how violence is a common experience in the sex industry. The term "sex industry" is used here in place of 
the more commonly used "sex trade". Through my research, many subjects identified the term "sex trade" as offensive, as it implies that sex work is a career choice rather than the exploitive relationship that it is in most cases; the term "sex industry" has been highlighted as more appropriate. Women and youth in the sex industry have reported being routinely subjected to many forms of oppression and violence, including: sexual harassment, verbal abuse, stalking, rape, battering, and torture (Farley, 2003). In Canada, the discourse around missing and murdered Aboriginal women (Cauchi, 2016; Welch, 2014), the fact that we have over 10,000 children in care of the Manitoba's Child Protection agencies (Puxley, 2014), as just one provincial sample, and the mere fact of women and children being exploited and murdered-all point to the urgency of this issue and call for action and change (Smith, 2014 a,b,c; Brownell, 2012). This research seeks insights from a wide range of perspectives into how service providers, practicioners, survivors, and other community stakeholders may better collaborate to address systemic issues to reduce sexual exploitation. It also examines the impact of laws, policies, and practices as they affect sexually exploited persons.

\section{METHODOLOGY}

A qualitative approach was taken in order to capture the subjective perspectives and rich insights of experiential survivors and practitioners. Feingold (2010) described how statistics could be misleading, in particular with respect to phenomena such as the sex industry, which are difficult to measure. This research has sought instead to gather the stories of people directly involved (Senehi, 2009, Sandole et al, 2009). This research asks what can we learn from those working in the area of sexual exploitation, and from those affected by it? Some broad questions were asked of several distinct stakeholder groups including: 1) survivors who have been sexually exploited or trafficked for the purpose of sexual exploitation, 2) workers from government agencies who are mandated with public safety including police, prosecutors, social workers and politicians, and 3) community leaders and people involved with other non-government organizations (NGOs) working on issues around sexual exploitation and trafficking. Subjects were selected for their expertise and experience in the subject matter.

The research proposal was successfully defended in September of 2015, and approved by an esteemed panel of University of Manitoba professors comprised of the following: Dr. Sean Byrne and Dr. Jessica Senehi of the Peace and Conflict Studies program, Arthur V. Mauro Centre for Peace and Justice, and Dr. Rick Linden, Chair of Sociology at the University of Manitoba. The University's Research Ethics Board approved the research within guidelines established in the Tri-Council Policy Statement: Ethical Conduct for Research Involving Human Subjects established in 2001 by Canada's three federal research agencies: the Canadian Institute of Health Research, the Natural Sciences and Engineering Research Council of Canada, and the Social Sciences and Humanities Research Council of Canada.

An informed consent process was applied with every subject including questions about anonymity and whether or not they consented to be identified and quoted in subsequent literature. Most service providers were eager to weigh in and be quoted; however, some did choose to remain anonymous. Experiential survivors' interviews were all anonymized in order to protect them from any potential impacts from participation. Many of the service providers are also experiential survivors who now work helping people to exit the sex industry. Service providers and community leaders were asked the following questions:

1. Please describe your background and involvement in work around the sex trade.

2. Please describe one at a time, what do the terms prostitution, sexual exploitation, and human trafficking mean to you and do they differ?

3. What strategies and approaches exist or have existed around sexual exploitation; how have they become more or less effective, and what should be done going forward?

4. Have practices of service agencies been culturally sensitive, and how could this be changed or improved?

5. Is there a critical event or turning point for youth when they enter the sex trade; what could be done to prevent it?

6. What could help people exit the sex trade?

7. What affect do the laws and law enforcement have on the sex trade and what should the police be doing?

8. What barriers or opportunities exist within your organization and between organizations for doing the best job with sexual exploitation, and how could this be improved?

9. If anything was possible and money was not an object, what is the best thing that could happen in Canada around the sex trade and human trafficking?

10. Is there anything else you would like to add?

Questions for experiential survivors were similar, but included questions about how they personally were introduced to the sex industry, how were they recruited, and what might have helped them exit.

A grounded approach was taken, generating theory from the observations gathered from the participants (Creswell, 2007). A grounded method uses "inductive analysis, which means patterns, themes and categories of analysis come from the data; they emerge out of the data rather than being imposed on them prior to collection and analysis" (Patton, 1980). This semi-structured, grounded approach allowed, as anticipated, for elaboration on key issues that arose during the interviews. Most importantly, qualitative interviews allowed me to gather impactful and insightful stories from the participants.

\section{FINDINGS AND DISCUSSION}

Overall, the uptake on the research has been inspiring, indicating there is a great deal of desire to make improvements. Forty interviews were planned and there was so much interest that over 65 were done. There was a great willingness of service providers, politicians, and community leaders to offer their insights. As anticipated, most subjects consented to be identified and quoted in the resulting literature, indicating they wished to weigh in on the issue. Sex trafficking survivors were also eager to participate and their insights were deeply moving and insightful. One significant theme 
that was prevalent in the survivors' stories and which was corroborated by the practitioners as well, was that the sex industry is not a living that most people choose; it is a violent and tragic existence that people are often manipulated and coerced into, and is difficult to escape.

My goal in this research is to make solid recommendations, based on the perceptions and stories of people in the know, with insights that may help us, as a society, to reduce peoples' vulnerability to being sexually exploited and assist those who wish to leave that life. This research aims to give voice to some who have not had the opportunity to be heard, and to acknowledge and highlight their perspectives. Another goal of this research, which dovetails with the intended outcome of solid recommendations, is community-building. In the interview consent process, all subjects were asked if they wish to be advised of the progress and outcomes of the research, as well as the thesis and literature that results from it. All subjects have expressed their wish to be informed. This has created a feeling of social movement around the issue. Further evidence of this has been the rewarding and humbling experience of being sought out by service providers and survivors wanting to participate and include their voices in this research.

While this phenomenon has been researched in various ways across Canada, there is room for much more, due in part to regional differences and changing social dynamics. For example, there is a growing awareness of the intergenerational impacts from colonization that affect many of today's First Nations, Métis and Inuit peoples. This research also will contribute to awareness of the dynamics of vulnerability and how predators expertly manipulate people into being exploited. The political landscape is constantly changing along with a growing public discourse on issues of vulnerability and social justice. This research is intended to add to that discussion. Hopefully, my recommendations and positive outcomes resulting from this research will be reported in future articles.

\section{ACKNOWLEDGMENTS}

Sexual exploitation and sex trafficking are difficult subjects to talk about, in particular for people who have been victimized in it, often having struggled off and on throughout their lives to escape, often struggling with childhood abuse issues, substance abuse, violence and poverty. It is also painful for people who work in service agencies, often for long hours with low pay, driven by compassion to help those who are vulnerable. Throughout this initial phase of my study I have been humbled by the openness of people and their willingness to share these deeply personal and often painful stories. I wish to acknowledge their contributions, and pledge to continue striving to amplify their voices and raise awareness on this important issue.

\section{CONFLICT OF INTEREST DISCLOSURES}

The author has no conflicts of interest connected to the submission of this article.

\section{AUTHOR AFFILIATIONS}

*The Winnipeg Police Service, Winnipeg, MB.

\section{REFERENCES}

Brownell M. Chartier M. Santos R., et al. (2012). How are Manitoba's children doing? Winnipeg, MB: Manitoba Centre for Health Policy.

Canadian Women's Foundation. (2014). From heartbreaking to groundbreaking: Stories and strategies to end sex trafficking in Canada
Toronto, ON: CWF. Available from: http://canadianwomen.org/ sites/canadianwomen.org/files/CWF-TraffickingReport-Donor-ENweb.pdf

Cauchi, E.D. (2016, January 28). Canada's missing: Thousands of lost or murdered Indigenous women. New York: Al Jazeera America. Available from: http://america.aljazeera.com/multimedia/2016/1/canadamissing-indigenous-women.html

CISC. (2008). Organized crime and domestic trafficking in persons in Canada (Strategic Intelligence Brief). Ottawa, ON: CISC. Available at: www. cisc.gc.ca/products_services/domestic_trafficking_persons/document/ sib_web_en.pdf

Creswell, J. (2007). Qualitative inquiry \& research design: Choosing among five approaches, 2nd edition. Thousand Oaks, CA: SAGE Publications.

Farley, M. (Ed.). (2003). Prostitution, trafficking, and traumatic stress. Binghamton, NY: Haworth

Feingold, D. A. (2010). Trafficking in numbers: The social construction of human trafficking data. In P. Andreas \& K. M. Greenhill (Eds.), Sex, drugs, and body counts: The politics of numbers in global crime and conflict (p. 46-74). Ithaca: Cornell University.

Manitoba Family Services and Housing. (2008). Tracia's trust. Winnipeg, MB Government of Manitoba. Available from: http://www.gov.mb.ca//s $/$ traciastrust/

Nelson, J. (2014, May 20). Modern-day slavery generates billions: UN report. Toronto, ON: The Globe and Mail. Available at: www.theglobeandmail. $\mathrm{com} /$ report-on-business/international-business/modern-day-slaverygenerates-billions-according-to-new-report/article18768332/

Patton, M. (1980). Qualitative evaluation and research methods. Beverly Hills: Sage.

Puxley, C. (2014, November 18). Manitoba wants fewer kids in care put up in hotels. Winnipeg, MB: Global News. Available from: http:// globalnews.ca/news/1678529/manitoba-wants-fewer-kids-in-careput-up-in-hotels/

RCMP (2014). Human Trafficking National Co-ordination Centre. Statistics: Human Trafficking in Canada. (March) http://www.rcmp-grc.gc.ca/ ht-tp/index-eng.htm

Sandole D., Byrne, S., Sandole-Staroste I., et al. (2009). Handbook in conflict analysis and resolution. Oxford: Routledge.

Senehi, J. (2009). Building peace: Storytelling to transform conflicts constructively". In Handbook of conflict analysis and resolution, pp. 201-215. Sandole D., Byrne, S., Sandole-Staroste I., et al. (Eds.). New York: Routledge Publishing

Smith, J. (2014a). The tipping point: Tackling the demand for prostituted/ trafficked women and youth. Retrieved from: http://freethem.ca/wpcontent/uploads/2014/02/The-Tipping-Point-MP-Joy-Smith-Full-ReportFEB-12-2014.pdf

Smith, J. (2014b). Connecting the dots: A proposal for a national action plan to combat human trafficking. Retrieved from: http://ncwba.org/ wp-content/uploads/2014/01/Combating_Sex_Trafficking-SmithNational_action_plan.pdf

Smith, J. (2014c) Constituency website. Available at: www.parl.gc.ca/Parliamentarians/en/members/Joy-Smith(25533)

Smith, J. (2013). Two private member's bills that made Canadian history. Can Parliamentary Rev, (Spring):4-6. Available from: http://www.revparl. $\mathrm{ca} / 36 / 1 / 36 n 1 \_13 e \_S m i t h . p d f$

United States Government. (2014). Trafficking in persons report. Washington Department of State, Office to Monitor and Combat Trafficking in Persons. Available at: www.state.gov/j/tip/rls/tiprpt/2014/index.htm

UNODC. (2014). Global report on trafficking in persons 2014. New York: United Nations. Available at: www.unodc.org/unodc/data-andanalysis/glotip.html

Welch, M.A. (2014, January 24). New database lists 824 murdered, missing native women in Canada. Winnipeg, MB: Winnipeg Free Press. Available from: http://www.winnipegfreepress.com/local/grim-number jumps-in-study-241776001.htm 